\title{
Narratives of Sustainable Indian Urbanism: The Logics of Global and Local Knowledge Mobilities in Chennai
}

Kirsten Hackenbroch and Christoph Woiwode

\section{(2) OpenEdition}

\section{Journals}

Electronic version

URL: http://journals.openedition.org/samaj/4190

DOI: 10.4000/samaj.4190

ISSN: 1960-6060

Publisher

Association pour la recherche sur l'Asie du Sud (ARAS)

Electronic reference

Kirsten Hackenbroch and Christoph Woiwode, « Narratives of Sustainable Indian Urbanism: The Logics of Global and Local Knowledge Mobilities in Chennai », South Asia Multidisciplinary Academic Journal [Online], 14 | 2016, Online since, connection on 03 May 2019. URL : http:// journals.openedition.org/samaj/4190; DOI : 10.4000/samaj.4190

This text was automatically generated on 3 May 2019.

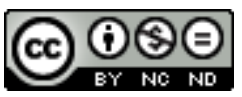

This work is licensed under a Creative Commons Attribution-NonCommercial-NoDerivatives 4.0 International License. 


\title{
Narratives of Sustainable Indian Urbanism: The Logics of Global and Local Knowledge Mobilities in Chennai
}

\author{
Kirsten Hackenbroch and Christoph Woiwode
}

The research presented here was generously supported by the Indo-German Centre for Sustainability (IGCS), IIT Madras, and funds provided by the German Academic Exchange Service (DAAD). Part of the research was carried out with a seed fund from the Indian Institute for Human Settlements (IIHS) under the project title "Climate change and socio-cultural transformation for sustainable living in urban India." Another part of the research was supported through an IGCSDAAD-postdoctoral scholarship for the project "Global visions and local realities of sustainable urban development."

We are grateful to our research and student assistants at IIT Madras who helped with fieldwork and transcriptions of interviews. Our sincere thanks goes to the editors who invited us to contribute to this special issue in the first place and made valuable suggestions that helped improve the paper. Equally, we cannot give enough thanks to the two reviewers for their detailed comments and probing of the text which encouraged us to work out the argument more clearly.

\section{Introduction}

After 100 days in office, the Indian Prime Minister renewed his commitment to develop "100 smart cities" for India in September 2014. He forged international ties with Japan, China, Germany and France, among other countries, for enhanced partnership in sustainable economic development and investments in urban infrastructure. Meanwhile, Singaporean politicians and consultancy firms visited the new state of Andhra Pradesh ${ }^{1}$ to pledge support in constructing its new capital city Amaravati, exporting not only pre-cast green buildings but their concepts of white board hyper-modern city planning. This may be seen as a case of both global mobilities of knowledge and globally mobile financial 
capital considerably influencing the pathways of Indian urbanism. ${ }^{2}$ It suggests the dominance of a growth-based urban agenda to future-proof cities for sustainable development in order to leapfrog them into the $21^{\text {st }}$ century. Simultaneously, however, various local emerging actors suggest the possibility of different trajectories of living urban sustainability. These actors work in social niches to pioneer new ideas, values and practices, a trend currently witnessed all over the world (WBGU 2011).

2 The actors in the first narrative of Indian urbanism-exemplified by the discourse on Amaravati-draw on global knowledge mobilities in linking local urban developmentwhether infrastructure or governance issues-to global best practices. Global knowledge mobilities $^{3}$ refer to actors-e.g. lobbying and consulting groups-learning and utilising ideas and concepts from elsewhere and transferring these to new localities and contexts. In conjunction with global travelling of people there is also a travelling of knowledge. Such travelling, however, is not unidirectional, but relational and embedded into networks. What travels when and to where is thereby embedded into power relations, illustrated by particular best practices in tackling urban development-such as smart city concepts-having become highly mobile around the globe, whereas other successful responses remain contextualised and comparatively immobile. The actors of the second narrative of Indian urbanism-exemplified by transformative mo(ve)ments towards sustainable consumption and lifestyles from below-often also form part of global knowledge mobilities. However, rather than importing powerful examples from elsewhere they incubate change by adapting quieter practices of sensitising societal groups for larger socio-ecological transformations. Both narratives can be observed in Chennai, a metropolitan city of 9 million inhabitants in South India. Technicalinfrastructural interventions based on global knowledge mobilities appear to determine the development of peri-urban areas and large-scale urban infrastructure for sustainable cities. At the same time, local initiatives such as the Chennai Green Bazaar ${ }^{4}$ appropriate spaces in the city with a view to triggering a discourse on alternative pathways to urban sustainability.

3 In response to the Special Issue's three theoretical strands, this paper seeks to situate the two narratives of the Indian discourse on urban sustainability within (1) discourses on urban citizenship and city making, (2) the role of knowledge in environmental politics and (3) a situated urban political ecology. This article explores the two narratives of urban sustainability, one driven by the notion of economic growth, future-proofing and infrastructure investments, which we identify as "internationalisation and globalisation of Indian urbanism," and one inspired by "quiet sensitisation," which we term "glocalisation through people's initiatives from below." They may seem to be antithetic, yet current forms of Indian urbanism may oscillate between both narratives, thus focusing attention on points of confluence as well as on disruptions between these two narratives. With private investment-driven and export-oriented growth-based urban agendas-often summarised as "neoliberal" and characterised by investments in physical infrastructures enabling economic prosperity-being as much on the rise as alternative visions of urban living-e.g. manifested in former IT-sector high-skill workers becoming organic farmers-this is a decisive moment for the social inclusiveness of urban development.

Following a brief outline of the methodology, we specifically ask which urban change and development planning practices currently constitute sustainable Indian urbanism by focusing on ongoing academic and public debate in India. The growth-oriented narrative 
suggests wide economic participation, triggering urban prosperity (World Bank 2009, Homm 2014, UN-Habitat 2012), whereas stories "from below" seek to challenge this economic vision of inclusiveness. In Section 4 we provide empirical evidence for the two narratives, drawn from our research in Chennai on negotiations of urban visions and green aspirations. We investigate the scales of socio-spatial inclusion embedded in the two narratives, and how these relate to global knowledge mobilities. As our results suggest, the narrative of green aspirations attempts to build inclusiveness by, for example, providing secure livelihoods to farmers, reconnecting the producer with the consumer, and thereby creating awareness for ecological, social and economic interdependencies. Concluding, we identify the characteristics of current forms of sustainable Indian urbanism and relate our findings to the three theoretical strands of this Special Issue on environmental politics in urban India.

\section{Methodology}

The paper is based on analysis of current academic and public debate in India and on the analysis of empirical material. Both emerged from two research projects conducted by the authors at the Indo-German Centre of Sustainability at the IIT Madras, Chennai in 2014 and 2015, namely "Climate change and socio-cultural transformation for sustainable living in urban India" and "Global visions and local realities of sustainable urban development: exploring strategic urban environmental politics and emerging (social) spaces."

6 Qualitative interviews were conducted in September 2014 and from February to May 2015 with government officials, lobby groups, research institutes, NGOs and individual citizens engaged in fields of sustainable urbanism. To protect the identity of respondents and conform to our ethical standpoint, organisations and individuals are kept anonymous. Actors were targeted based on an explorative approach that started with themes of sustainable urbanism, i.e. urban green spaces, urban gardening, walkability or sustainable public transport. Initial following of debates in local newspapers and first interviews led to the comprehensive exploration of the arenas within which different actors operated. Those interviewed comprised persons whose jobs involved them in shaping narratives of sustainable urbanism-whether by assignment or by personal conviction or both-as well as persons who contribute their free time as active citizens. A comprehensive English media analysis of The Hindu, The Times of India (both pan-Indian newspapers with Chennaieditions) and the DECCAN Chronicle (a Tamil Nadu newspaper) supplemented the interview materials.

\section{Narratives of sustainable Indian urbanism}

Sustainable urbanism has often become an alternative term for something city governments have long sought: growth-oriented economic development that places a city high on rankings of competitiveness and liveability (e.g. Kaika and Swyngedouw 2014). The recent trend of policy exports in the field of sustainable urban development by large companies and consultancies, but also between state agencies, speaks to this assumption of a "sustainability fix" (Temenos and McCann 2012); here the authors especially emphasise the extra-local component of a politics of policy mobility. For example, the mobility of the smart city as a global model can be understood as an attempt to deliver 
sustainable urbanism following the logic of global entrepreneurialism and thereby creating an attractive environment for the global economy (see Wiig 2015, based on an analysis of IBM's Smarter Cities Challenge and a particular case study of Philadelphia). These academic debates suggest a continuation of previous urban agendas, clad in a rhetoric of sustainability. In the two narratives that follow below, the explanatory value of this understanding of urban sustainability is tested with regard to academic and policy discourse on Indian urbanism. The question is whether and how sustainability becomes absorbed into recent debates on Indian urbanism.

8 To look beyond what currently guides-or dominates-urban scholarly debates on sustainability, we build on last decade's "southern turn" or "worlding turn" in urban studies, initiated by understanding cities as ordinary (Robinson 2006, Roy 2009). Since then, the discussion has been gathering momentum, even though urban theory from the South or a worlding of southern experiences is yet to materialise in what has been called the Western or European-American domain of urban studies. Furthermore, uneasiness remains when considering the claim of theory from the South as "the locatedness of the global south does not imply a single and stable location" (Roy 2014:15). Rather than a geographical category, the category "South" refers to a specific "dual situation of postcoloniality and particular political economy" (Mabin 2014:22). The observation that drivers of change in Southern cities are multiple brings Parnell and Robinson (2012) to suggest the decentring and provincialising of recent work on neoliberalism-as a hegemonic discourse in Euro-American (critical) urban theory-with reference to processes in the South. Rather than seeing the state as supporting a "hegemonic agenda of competitive privatization and minimal welfare provision" (Parnell and Robinson 2012:610), the state-including the diversity of actors, agendas etc. within it-should be analysed in its potentialities for innovation and a pro-poor agenda. This, however, does not signal a developmental theorising of southern urban studies with categories of megacities, slums and squatter settlements or informal economies but enables the establishment of a more grounded analysis of modes of the production of space, for example constituted of "peripheries, urban informality, zones of exception and grey spaces” (Roy 2011:224).

Nair (2013) asks whether there is an Indian urbanism and if so where it is historically grounded. Her answer is ambiguous: state agencies now operate in an assemblage where the aim is "to reconcile the economic demands of global finance capital (the economy) with the compulsions of the political, rooted in local power structures" (Nair 2013:61, original emphasis). Simultaneously, a "fantasy of totalized planning" (Nair 2013:62) charged with a colonial legacy and subsequent post-independence legislative and organisational amendments of modernist planning remains in place and continuously reinstalls itself (UN-Habitat 2009:50-59). This process has gradually resulted in opaqueness in applying planning regulations and control, thus bringing exceptionalism to the forefront of this Indian urbanism.

\section{Narrative 1: "Internationalisation and globalisation of Indian urbanism"}

Two globally mobile urbanisms-i.e. narratives of urbanism that travel globally and become both dislocated and located (see e.g. McCann and Ward 2011)-have recently found their way into debates concerning sustainable Indian urbanism. First, the debate on 
cities and climate change, largely based on a developmental mode of urbanisation. Second, the smart city debate that fits the politics of Prime Minister Narendra Modi, largely framed around an entrepreneurial mode of urbanisation. Both are discussed here, as they are illustrative of other developmental and neoliberal processes that make up the reproduction of space in Indian cities.

\section{Climate change action}

11 In Europe, climate change long ago entered into urban policies and planning. What has informed a new politics of climate change governance is the emergence of strategic partnerships between the public and a range of private actors as well as a reconstitution of the state as an arena for societal discourse, negotiations and concerted action. The resulting actions can take the form of striving for security and resilient cities infrastructure; however, they can also involve the enabling of self-sufficiency initiatives (Bulkeley and Betsill 2013).

12 In India, Delhi-a city experiencing persistent droughts, more frequent heavy rainfalls, rapidly increasing GHG-emissions and diminishing air quality-was the first city to adopt a climate change action plan in 2009. The action plan was seen as an opportunity for urban infrastructure development:

[T] he city government seized the momentum generated by climate change discussions to push its own development agenda. In this regard, it is interesting to see how pressing development needs-such as the need to provide basic infrastructure for water, sanitation, waste management and transportation-are bundled in the Plan with a "climate friendly agenda." (Aggarwal 2013:1913)

13 The plan speaks to the world-class ambitions of Delhi, and climate change provides the city government with an argument for mobilising broader support for their development agenda (Aggarwal 2013:1913). In Chennai, grounding urban planning in an abstract climate-change scenario turned out to be more of a political exercise than a practical planning concern, both for city authorities and environmental action groups. Drafted by experts from Kyoto University in cooperation with the University of Madras and the Corporation of Chennai ( $\mathrm{CoC}),{ }^{6}$ the Chennai Climate Change Action Plan emerged as a highly contested document. It was submitted to the $\mathrm{CoC}$ in 2011, but due to local and state elections it was never approved by the city council and state government. Several years later this plan seems to be conveniently forgotten, as it is virtually impossible to get hold of. Complementing this plan, a profile was developed to assess the resilience of each zone in Chennai's pre-2011 administrative city limits. Both these documents were designed to facilitate the expansion of the city's jurisdiction, particularly with view to the integration of infrastructure like water supply, sewerage treatment and storm water drainage to reduce disaster risk (Shaw and Krishnamurthy 2010).

14 The fuzzy urban climate change agenda has de facto not reached the actors, and the policies and actions that evolved or were implemented are centred on previous discourses and approaches. New concepts of how to deal with cities under conditions of climate change did not emerge. This, again, illustrates how the climate change agenda is used to support developmental urbanism and reframes a planning practice that remains "old school," guided by enabling infrastructure projects, enacting legislation and by-laws for construction, and establishing mechanisms of building regulation. In Nair's words, this can be understood as continuing the "fantasy of totalized planning" (2013:62). 


\section{Smart cities}

15 Smart cities are the second mobile urbanism in the debate on India's cities. Announced by Prime Minister Modi in 2014 to boost economic growth and urbanisation, the latter considered the necessary companion of the former, the programme aims at developing 100 smart cities:

Cities in the past were built on riverbanks ... They are now built along highways. But in the future, they will be built based on availability of optical fiber networks and next-generation infrastructure (Modi, quoted in Tolan 2014).

For the new Smart Cities Mission, the Ministry of Urban Development (MoUD) has selected twenty cities ${ }^{7}$ deemed fit to become "smart." A key objective of the mission is to capacitate municipalities, especially the hitherto politically largely weak mayors, to attract funds from private investors to implement large-scale projects. The logic behind this is "to generate as many urban centres as possible and ensure a double digit GDP" (Jeelani 2015).

17 The underlying implication is that smart cities are "by default" sustainable and, naturally, also climate-proof, even though the latter is not a stated goal of the programme; rather a sort of taken-for-granted attitude that technological solutions will inevitably lead to sustainable and resilient cities. This almost blind belief in technological fixes to resolve India's urban challenges seems evident not only in that part of the public media discourse driven by the corporate sector, but also in the Government of India's programme documentation in which social inclusion, equity and participation assume more of a rhetorical status (MoUD 2015). Paired with this simplified, techno-scientific approach to urban development is the neglect of people as actors of everyday urban life, and thus of the social aspects of sustainability, such as aspiring for socio-spatial justice and local democratic accountability in decision making. A case in point is the failure of the public online participation campaign by the $\mathrm{CoC}$ in 2015, which received a meagre number of suggestions on how to smarten up the city. More importantly though, both the media and the $\mathrm{CoC}$ concluded that many residents "[had] not offered the right suggestions," for they mainly addressed ad-hoc issues such as road improvement or desilting of drainage without considering more long-term and transformative projects (Lopez 2015). ${ }^{8}$ On the positive side, the process initialised an increasing awareness that there is tremendous scope and need to overcome top-down, selective, and opaque participation processes. For instance, a public hearing was held by the $\mathrm{CoC}$ in 2015 where citizens could vote for the area they would like to see developed within its smart-city proposal.

18 Soon after smart cities entered the Indian debate they were critiqued for their marked shift towards entrepreneurial urbanisation and away from social justice (Datta 2015). By using Dholera, a smart city along the Delhi-Mumbai highway corridor initiated by Modi during his term as Chief Minister of Gujarat, Datta (2015) tracks the origin of the concept and its transformations from a corporate mobile urbanism (Wiig 2015, McCann and Ward 2011) to Indian politics. It ends as a scaled-up state model deemed a solution to India's urban question and a vision of Indian (hyper-)modern urbanism. What this hardly accounts for are its citizens-while the young urban groups and property-building classes are obviously addressed, statements from the corporate sector reveal the exclusionary vision that accompanies the smart city notion (Aam Janata 2015). 

impression that entirely new cities will be built. Only very few smart cities are going to be "new towns," as the programme outlines three areas of intervention: retrofitting, redevelopment and greenfield development. Particularly with the latter, there are serious issues related to environmental impact and land acquisition, often undermining the very idea of sustainability. This is apparent in Ponneri, a town on the northern edge of Chennai, where a greenfield smart city extension is now being planned across 3,000 hectares by a Japanese firm with funding from Japan International Cooperation Agency (JICA). ${ }^{9}$ Even before its conceptualisation, the acquisition of agricultural land for urban and industrial development elicited protests. In addition, the current town is situated within a water catchment area crucial for providing water resources to Chennai and is already affected by seawater intrusion (Vijay 2014).

As a mobile urbanism, smart cities in the Indian policy debate suggest a strengthening of "neoliberal" agendas, based on a doubtful Gujarat state model (Hirway and Terhal 2002), repeatedly rendered an Indian "best practice" by its (political and economic) supporters and assessed in various media (e.g. The Economist 2015). Interestingly though, the smart cities discourse has also triggered debate about urban futures. There are cautioning calls that smart cities may be "technobabbles about our collective future not very different from the dreams which other technologies once generated" (Nair 2014). Smart cities, these critical voices argue, cannot only be about technology solutions but fundamentally have to be equitable in order to be socially inclusive (Nair 2014, Srivathsan 2014). Social inclusion remains a big question mark with this approach of capital intensive high-tech urbanisation. There is the danger that these urban expansions become exclusive gated communities, thereby increasing social distance while (re-)generating hierarchies of religion, caste and income and becoming a "Dream de la crème" (Dixit 2015) for a few. This policy mobility is contrary to the notion of a city for all: "The dream of the 'smart city' is a morally and socially indefensible one in a deeply segmented and hierarchical society like ours, in which the quest for meeting the basic needs of its citizens, even decades after independence, has been all but abandoned' (Nair 2014). One is left to wonder how the smart cities vision differs from past urban development and rejuvenation schemes, apart from information technology-already part of the life of the wealthy in India though not yet translated into effective e-governance. The essential question remains whether this vision can transform the qualities of urban citizenship and improve the lives of India's urban dwellers in coming decades.

\section{Narrative 2: "Glocalisation through people's initiatives from below"}

Besides these two narratives at the national scale other knowledge mobilities speak of middle-class sustainable urbanism based on a project of learning and greening the city, a discovery of lifestyles relatively novel in urban India (not necessarily sustainable but health-oriented-gyms and yoga, organic/health-food conscious, e.g. Sneha 2014), perhaps signalling a renewed influence of the spiritual on modes of the production of space and conscious sustainable living. This will be the first of our explorations of glocalisation, i.e. the global intermeshing with local processes and transformations. Yet beyond this, neoliberal and developmental urbanisms are frequently disrupted by what Benjamin (2008) referred to as "occupancy urbanism"-the (brief) second of our explorations on glocalisation below.

South Asia Multidisciplinary Academic Journal, 14 | 2016 
22 First, this narrative can be placed theoretically within transition or transformation research characterised by experimentation, practices of learning and transdisciplinarity (Grin, Rotmans and Schot 2010, Liedtke et al. 2015, WBGU 2011). Here, the role of civil society and citizens as drivers for deeper, fundamental change is becoming a globallyrecognised need and phenomenon (Goldstein 2006, WBGU 2014). Characteristically, in many countries these societal groups and initiatives have their roots in environmental, development and climate-protection movements, religious communities and trade unions (WBGU 2014:71). Such collectives and individuals act as social pioneers to spearhead innovative social practices. Hence, learning is situated in an evolving methodology of "living labs" where people-academia, corporate sector and government-experiment within a transdisciplinary framework to develop, test and upscale innovative solutions towards sustainability transition (Liedtke et al.2012, Schneidewind and SingerBrodowski 2013:125-28). In "Learning the City" McFarlane (2011:1) conceptualises learning as "an important political and practical domain through which the city is assembled, lived and contested, and as a critical opportunity to develop a progressive urbanism." Learning here is furthermore understood as a process of creating knowledge, of translating what was learned to a particular context and of learning how to use and access knowledge produced by others. This puts forward Indian urbanism as a set of (mobile) "worlding practices" (Roy and Ong 2011) comprised of processes of learning, whether experienced in the field of individual or societal consciousness or the political, as in "occupancy urbanism" (see below).

A relatively new phenomenon, which is hitherto underexplored in academic research, is the "greening" of the urban "middle-class" visible in an avant-garde or activist environmentalism from below in cities like Bangalore, Chennai or Hyderabad, which intends to incubate action towards social transitions to sustainability. Findings from our study indicate, with a few exceptions where cooperative networks are being built, these are primarily local niche activities by small citizens' groups or even individuals, ranging from organic food initiatives, kitchen gardening, composting, upcycling, and promotion of cycling to organising car-free Sundays. Beyond that, interviewees framed their activities more holistically, with regard to interdependent global issues of climate change, environmental degradation, social justice and the attendant crises caused by past development paths. Their engagement within the range of their own lives at the sociallocal level is thus based on an urgency to act as responsible citizens.

In contrast to such niche activities, elite and middle-class "bourgeois environmentalism" has a different history in shaping urban spaces in India. Environmental arguments have long been used by neighbourhood organisations and religious groups to fight for their own share in city spaces, whether by legally challenging "the nuisance of slums" (Ghertner 2010) or by using a strategy of unmapping river floodplains for slum evictioni.e. creating conditions of exceptionalism and deregulation-and thus clearing the ground for subsequent state and religious groups' megaproject construction in the very same places (Follmann 2015).

Second, almost diametrically contrasting the previous, the narrative of glocalisation also incorporates practices of learning that are characterised by political moments of mobilisation. This reading of the narrative lends agency to different groups of citizens, most prominently to the urban poor, in making their claims to urban spaces in Indian cities. This is inherent in Appadurai's (2001) account of the "politics of shit," where the poor, making use of everyday knowledge of their own livelihoods and life worlds, become 
active subjects by organising toilet festivals to force World Bank officials into learning about local realities and solutions. By these forms of "counter-governmentality" the slum dwellers claim political citizenship and recognition at local and international levels. Similarly, community enumerations and community mapping-established knowledge mobilities within a network of international organisations as represented by Slum Dwellers International-have become means for groups often denied full citizenship rights to claim recognition and participation in urban policymaking (e.g. Patel, Baptist and D'Cruz 2012, Appadurai 2012).

To frame this reading of the narrative with regard to learning and sustainability transition, the distinction between civil society and political society (Chatterjee 2004) is helpful. Civil society, Chatterjee argues, appears "as the closed association of modern elite groups, sequestered from the wider popular life of the communities, walled up within enclaves of civic freedom and rational law" (Chatterjee 2004:4). Political society is then what is available to the poor or marginalised groups to make their claims to a diversity of resources. In urban areas such political "worlding practices" may include occupancy urbanism (Benjamin 2008) and the durability of institutions and coalitions formed to fight for a share in urban space for the poor (Weinstein 2014a, 2014b). Such practices, however, are based on disruptions of the concept of citizenship.

The narrative of "Glocalisation through people's initiatives from below" consists of multiple readings and is characterised by diverse practices and processes of learning. These multiple readings first include initiatives grounded in the search for a sustainable lifestyle aimed at visions of societal transition or general liveability in the city, and, second, initiatives that seek recognition for their reproduction of urban spaces via political mobilisations. The spectrum of actors is highly diverse, ranging from groups excluded from full notions of citizenship to globally-mobile urban professionals. Accordingly, the range of ideas, types of knowledge mobilities and approaches to sustainability are equally diverse. The struggle of the urban poor for housing, water and sanitation-the prime needs of a high percentage of India's urban dwellers-taps into global mobilities of knowledge, linking up to global political movements and seeking social inclusion in urban areas. Such initiatives, nonetheless, seldom move beyond their scope of action within political society, and thus do not shape a larger debate on sustainability transformation in Indian urbanism. In the following, we focus on social niche activists-based on our empirical evidence and the above analysis that illustrated the advanced body of literature available on mobilisations of the urban poor.

\section{Negotiating forms of urbanism: Case studies from Chennai}

Over the course of several decades Chennai has emerged as one of India's largest industrial centres with a concentration of international automobile industries and, more recently, the IT-industry (Hill and Woiwode 2016, Homm 2014). A rapidly-growing agglomeration, it lacks the global city ambitions so strongly present in urban developments in Delhi and Mumbai (Ghertner 2010, Gururani 2013, Schindler 2014, Follmann 2015, Weinstein 2013, Gandy 2008). Neither does it have the sensational ITbased growth that has accelerated the expansion of Bangalore (Benjamin 2008, Goldman 2011) or Bangalore's diversity of social and "green" movements and middleclass mobilisations (Kamath and Vijayabaskar 2009). Finally, Chennai does not have the 
communist legacy which has made Kolkata specific in terms of its land-management and territorial politics (Roy 2003). With its industrialisation comparatively balanced in different sectors (e.g. automobile, IT, logistics), rather discreet or at most selective globalcity ambitions and a local-traditionalist perspective on emerging narratives of urbanism, Chennai can instead be framed as ordinary among the largest Indian cities. This "being ordinary" may allow an analysis of current urban processes that is not blinded by "the global" as a category of urban-space production, nor by an empirical overemphasis of the urban poor's right to the city or the developmentalism of the NGO scene-all rather dominant features of the debate on Indian cities (Shatkin 2014).

As in other Indian cities, from 2005 the JNNURM directed infrastructure investments in Chennai. Its requirement of establishing City Development Plans following a participatory planning process was, however, weakly implemented and only gained small momentum when the process was funded by the City Development Initiative Asia (CDIA), a programme of the German Development Cooperation and the Asian Development Bank (ADB). Several groups of affected or interested citizens and activists never joined the process, suspicious that their participation "would lend legitimacy to a scheme that they opposed" (Raman 2013:294-95), e.g. to a vision of urban infrastructure that prioritised motorised individual transport options over pedestrians and public transport. This meant that a chance to create a culture of larger public debate and the formation of political opposition was only used by a fraction of the city's public (Raman 2013). This is symptomatic of many urban processes to date. While coalitions between diverse groups emerge on a programme or project-basis, there is no larger public debate. This argument was voiced during a workshop held by the Goethe Institute Chennai on "Water in the City" in March 2015 that federated academics, participants from civil society and cultural creatives. Based on the example of river-cleaning the participants discussed the issue of an "uninvolved citizenry." 10 They argued that the government used river cleaning as a way to clear slums and establish parks, whereas the larger causalities of river pollution are not broached-and no one asks the crucial question "How will the river get clean?" Public debate was absent in the eyes of participants, although a knowledge and debate space was deemed necessary. In the following, case studies from Chennai serve to illustrate the variety of narratives of sustainable Indian urbanism.

\section{Grand urban visions: Integrated infrastructure and planning the region}

In a continuation of the national debate on climate change action and smart cities, local urban visions that become powerful in Chennai are driven to a large extent by actorsstate institutions and policymakers, lobby groups, investors and industries, consultantswho successfully make use of mobile urbanisms and global "best practices." Sustainability in these actors' narratives translates into grand public infrastructure projects, interpreted in a technical-economic environment of a growth-oriented urban agenda. Social aspects of sustainable urban development and visions of an inclusive city have not been prominent.

Our interviews suggest that especially those visions of urban development that are based on "travelling knowledge" contribute to building "dominant" planning imaginaries for the city. Such planning imaginaries receive wide media attention, are backed by powerful players and invoke colourful images of the material aspects of modern urban living and 
liveability-manifested in 3D-drawings of futuristic public transport hubs or attractive pedestrian zones. One lobby group, which is enabled by support funds from industries and other market actors, has successfully drawn on such knowledge mobilities to link urban development to global "best practices" in both infrastructure development and urban governance. Such inter-referencing practices matter considerably for one of the group's activists:

So we are able to take experts. We are able to show the [government] official "Look, here's a boat, here's a lake, here's something, here's a bus depot, here's a metro station that is coming... Can we do it like this? ... Look at Hong Kong. Look at Singapore. Look at Berlin. Look at how they have integrated the storm water [drainage system]. Look at how the bus is integrated into the metro."11

Hong Kong, Singapore and Berlin feature as prominent reference points for the physicalmaterial built environment dimensions of high quality urban living throughout the interview, particularly for infrastructure, but also for planning enforcement. A newspaper analysis of The Hindu, The Times of India and the Deccan Chronicle for September 2014 arrived at similar reference points: Singapore government officials, planning and construction firms visited India to forge alliances to establish Andhra Pradesh's new capital. The German Foreign Minister visited India and cooperation was agreed upon in several fields of sustainable development affecting urban areas. Furthermore, in the interview Bangalore was inter-referenced as the model Indian city in many aspects of sustainable urban development. This Indian reference was important to all stakeholders in urban development and many initiatives had their roots in Bangalore.

A second dimension of this inter-referencing practice and the accompanying mobile urbanism is the translation of knowledge mobilities into local action. Here, effective formulation of visions and systematic working with the local state paves the way for concepts to be transformed into local policy initiatives, as the continuation of the above quote illustrates:

We create a concept. And show [it to] the government. They [the government] would say "Look, let's do it." Because what this problem with government is [, is] that they have money but no capacity. And it's a mistake to go ask government to go, ask them to do something. Yeah? ... There's no point shouting at you [here meaning: the government officials] and saying "You are corrupt. You are bad." The same way, we walk in Berlin, or Singapore and say "I saw great metro rail, ... I saw great footpath, what would you do?"-"I have no idea what you are talking about." They [government officials] want to. It's not like they don't want to. Nobody says "I wanna do a bad city." So anyway, so we bring expertise. So partnerships, through partnerships. ${ }^{12}$

Such a partnership between state actors and a lobby group able to forge a coalition with the state is what made Chennai the first Indian city to adopt a Non-Motorized Transport (NMT) Policy in 2014. Walkability had been the topic of many parallel initiatives for years, by citizen groups, researchers, Resident Welfare Associations (RWAs, see Figure 1), media campaigns and groups of the urban poor. The latter had suggested the prioritisation of the needs of pedestrians during the City Development Plan (CDC) process within JNNURM (Raman 2013:293). From this diverse arena of initiatives, a coalition of an active and interested state body, a pro-active lobby group and a (globally-operating) research and consultancy organisation emerged. The lobby group was initiated with the aim to bring together urban stakeholders outside government to assist in urban development decisions. Drawing on knowledge mobilities among its activists and tapping into the knowledge mobilities of global think tanks, they were able to bring in transportation 
consultants. This coalition of three actors then succeeded in drafting and formalising the NMT Policy that conveys a "grand vision" of developing NMT in Chennai (Vassileva 2015) and is considerably influenced by what has been discussed as best practices elsewhere. While a group of actors with the ability to bring in global knowledge mobilities forged a successful coalition for green infrastructure, others who had initially raised their voices did not formalise their imaginaries of a walkable Chennai. Current pilot projects and debates on pedestrianisation, for example, do not accommodate street vendors in the picture, causing activists and researchers to be highly critical of the benefits of the NMT policy.

Figure 1:

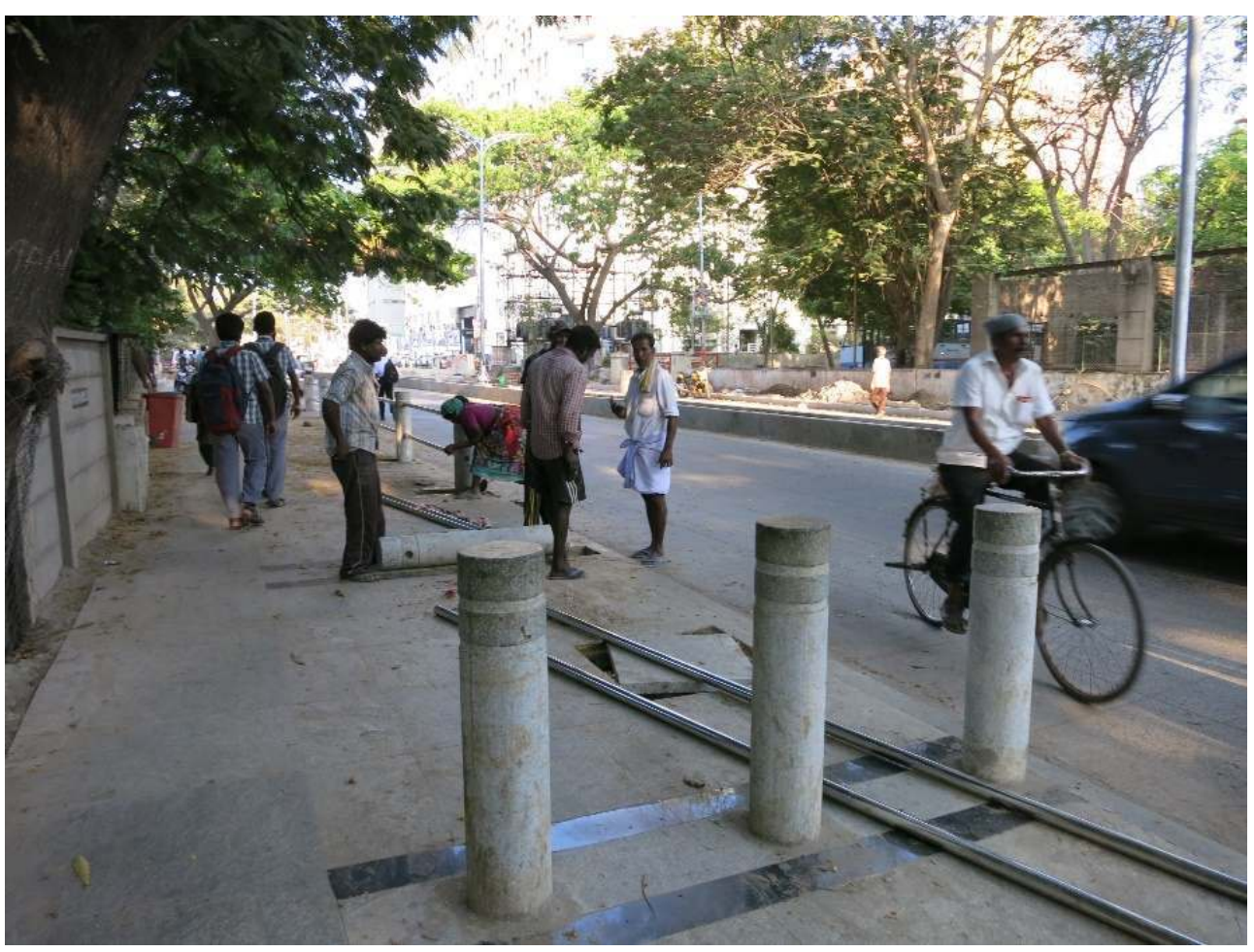

A WALKABILITY PROJECT IMPLEMENTED BY AN RWA IN CHENNAI 2015

(PHOTOGRAPH BY: K. HACKENBROCH)

The tensions and disruptions of sustainable Indian urbanism between the grand urban visions of Narrative 1 and the glocalist and quiet forms inherent in Narrative 2 become obvious when looking at two actors' ways of approaching the lack of green spaces in the city. The protagonist of the grand vision underlines the necessity of a regional perspective, manifested in a physical-spatial Leitbild, and a long-term vision of the city's future:

Why don't we now start planning a region, you know? ... Let's start planning the central parks of the future, 50 years from now; there will be central parks $50 \mathrm{~km}$ away from here, $100 \mathrm{~km}$ from here. Land is cheap. Let's buy it. I mean, city should buy it. Plan the future central park. Where is that plan? There is no plan, yeah? ... So you put a document there saying ok fine! Let's [do it now], because, many years ago, they looked at the bigger Chennai, this is how Chennai became bigger. ... Now we are with no sewage, no roads, nothing in a bigger Chennai. Now everybody is scrambling to figure out what to do about it. ${ }^{13}$ 
This is a vision of regionally embedded urban planning long called for, and every decade of city growth has illustrated how the lack of this grand vision has led to diminishing quality of life. Furthermore, cities with historic green spaces preserved despite urban growth, such as Bangalore's garden parks, continue to be celebrated for their liveability. The grand vision of green spaces, however, has not successfully been implemented in any post-colonial Indian city to date-and accelerating land values based on the industrial and real-estate demand for peri-urban land do not support such developments. The alternative approach brought forward by actors following the second narrative of sustainable Indian urbanism thus approaches a much smaller scale, focusing on learning and societal transition, as one initiator of a kitchen garden (see Figure 2) explains:

People have to realise it is a garden, it'll take time, the easiest thing is to just, okay, dig the soil, plant and these things. So it needs people to make the jump. That you're doing something sustainable, you're doing something that is baby steps. I mean if someone says "Let's do this to all the parks in the city," I think it's a great policy initiative, but you really need to think about how? Who? ... Because here, in 24 months a government can go, and [if] we haven't showed results, they are going to say "Oh, what happened to all that space?" It's not the money, it's the will. And, you know, the ability to watch and wait and take the steps, organically. ${ }^{14}$

Here, a practice of raising environmental awareness and of a quiet sensitisation is represented in the "baby steps" the interviewee refers to and the organic nature of the urban change process. The kitchen garden was initiated by a group of women, some of whom had lived abroad as non-resident Indians while all had visited other initiatives throughout India. They assembled their knowledge and discoveries to come up with something of their own they described as "going beyond individual plots and parcels" to create a group experience. Various knowledge mobilities from elsewhere were adapted to the local context, from setting up the soil to establishing a teaching garden. This alternative sketch of an urban future, based on smaller-scale space productions and sustainability transition will be further discussed in the following pages. 


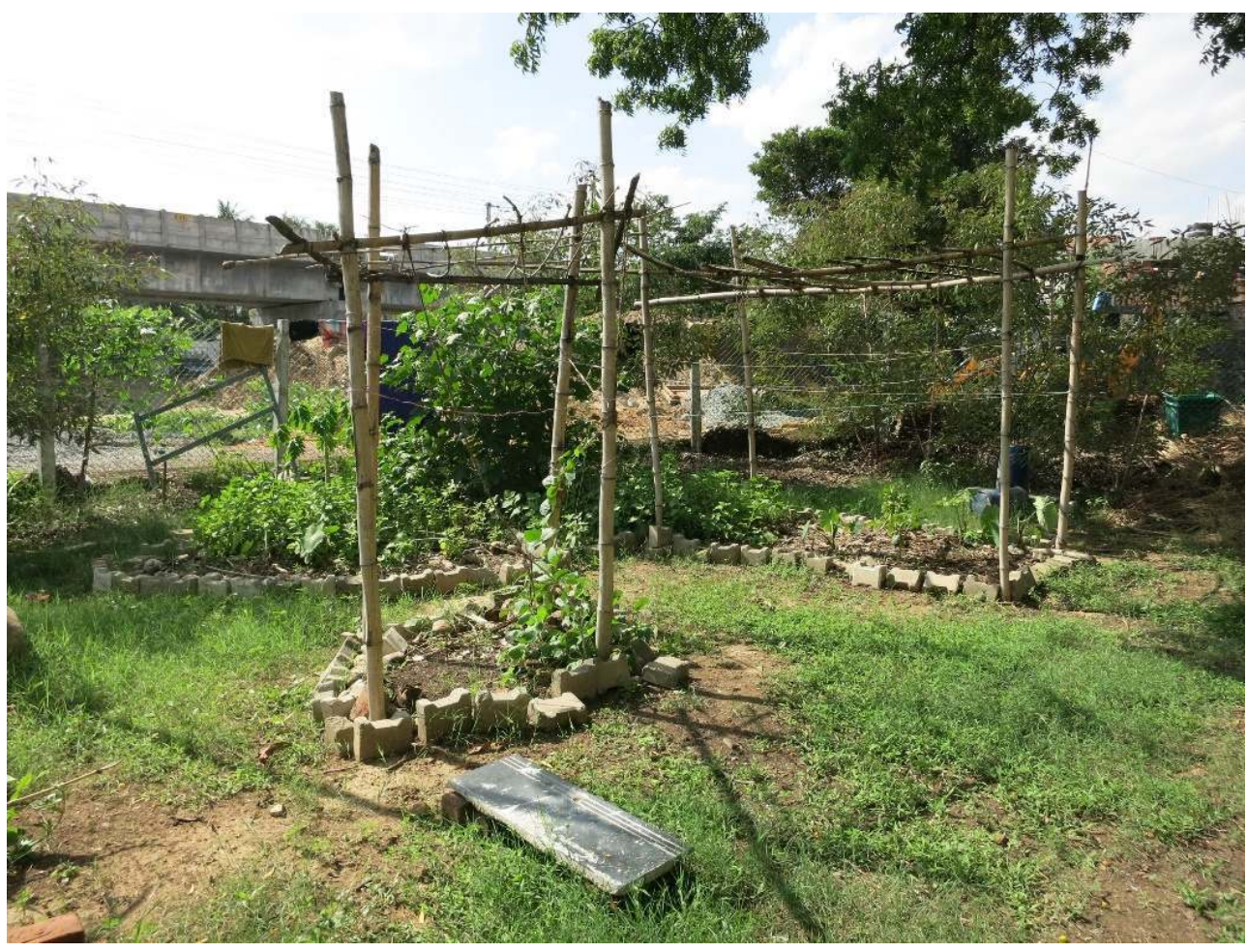

A KITCHEN GARDEN ON PREVIOUSLY UNUTILISED LAND IN CHENNAI

(PHOTOgRAPH BY: K. HACKENBROCH)

\section{Urban green aspirations: Environmental awareness, green lifestyles and urban agriculture}

As evident in the example of the kitchen garden, on a much smaller scale and in contrast to "grand urban visions," the production and negotiation of green spaces in the city gain momentum, whether as urban agriculture or community parks (Tornaghi 2014). These spaces could be conceptualised as mobile urbanisms, reiterated around the world, for example in numerous urban gardening initiatives and movements such as Transition Towns. ${ }^{15}$ Yet the "greening of the mind," as we call it, is probably a more important aspect of such initiatives-people start to think beyond ecology once they begin to fundamentally question the current economic system and perceive an ethical responsibility towards fellow human beings and the planet.

Our studies in Chennai ${ }^{16}$ identified three intermeshed levels, or scales, of such citizendriven sustainability, (1) a micro-level of local change, (2) a macro or more systemic level of societal change, and (3) a global meta-level about the grand challenges. On the microlevel the individual/small group begins a process of very personal, local change by way of lifestyle and/or consumption choices in sectors like mobility, waste, clothing, or gardening. For individuals, this commitment is often explicitly driven by a search for more meaning in life. Surprisingly, we encountered several people in their twenties who had exited the IT sector "to find something more fulfilling and meaningful" because they no longer liked their jobs, "only night shifts" and "too boring, you always sit in front of a screen!" There is a trend, observes one interviewee from "reStore." 17 
Yes, these are youngsters who were working in corporates. See, I jumped out of the corporate world at 35. I have seen people come out in their forties. But these are guys who have jumped out in their twenties. ... The salary they get here is probably half of what they got in their previous jobs but they derive a lot of job satisfaction from their work here. I would definitely call them volunteers. ${ }^{18}$

Interestingly, while these youngsters consciously discontinue their jobs, they are not necessarily pulled out by ideas of "sustainable living." In their search for more meaningful goals in life, concern for the environment and the planet is not their specific focus, yet during their quest many stumble over organic farming or the opportunity to run their own organic shop. They are receptive for they want to do something "meaningful" and "contribute to society," as they express it. In addition, this process of intense searching and commitment to a cause initiates a process we term the "expansion of the self," which is related to personal growth and a new way of thinking based on a learning journey initiated by the activities. Many of the interviewees point out that these new activities reframe their entire worldview, affecting life and family perspectives and understandings of the interconnectedness between I (the local), We (community) and Us (the planet). We may argue that this is the kind of fundamental shift in consciousness needed for a social-sustainability transition, usually accompanied by deeper concern for the future, as expressed exemplarily by a woman from a neighbourhood group on composting in Bangalore:

I have grown exponentially! So it's been unbelievable growth and I myself am shocked at the kind of balance I have, you know, all this kind, being in the space keeps you...... So if you are connected to something so important as caring for your planet or caring for your environment or climate, if you are caring, then you will stop being small, you don't waste your time on small things. So I think everybody... you have to passionately commit. ${ }^{19}$

41 This concern for the future and the planet links the individual with two other levels or dimensions, the macro or systemic and the global.

Accordingly, a macro or more systemic level can be distinguished as the second level, where initiatives attempt to induce societal and systemic change; for instance, by creating awareness and concrete action towards sustainable living (e.g. internet platform and Green Bazaar by "The Alternative.in," see Figure 3) or building cooperative organic food producer-consumer networks through what we identified as "social-ethicalecological entrepreneurialism" (e.g. "reStore" or "Nallakeerai" in Chennai). With these qualifying terms "social-ethical-ecological" we intend to grasp the comprehensive, or more holistic, approach and intention of these socially innovative agents who combine their activities with an entrepreneurial business idea. They cannot be simply placed in any single discourse of poverty alleviation, social justice, or environmentalism. The founding members of "Nallakeerai," an organic farming producer-and-consumer network located on the outskirts of Chennai, expressed this broader social vision combining a healthy society, economic viability and ecological sustainability:

Person 1: "We want to do something for the society and that's why we entered this field. What my friend had mentioned that for 15 to 17 years we had worked in corporates and we have seen how the corporate world functions."

Person 2: "We take the positive things from the corporate world and try to implement here."

Person 1: "We want to break the dependence the farmers have on pesticides and fertilisers. We want to break that attachment and create a healthy society."

Person 2: "We can run this as a business and it is like a win-win situation. It is a business at one point but it is fundamental to bring about social awareness and 
social health. And then giving a good model for the community. Of course when you do this together properly it is a viable business." ${ }^{20}$

Figure 3:

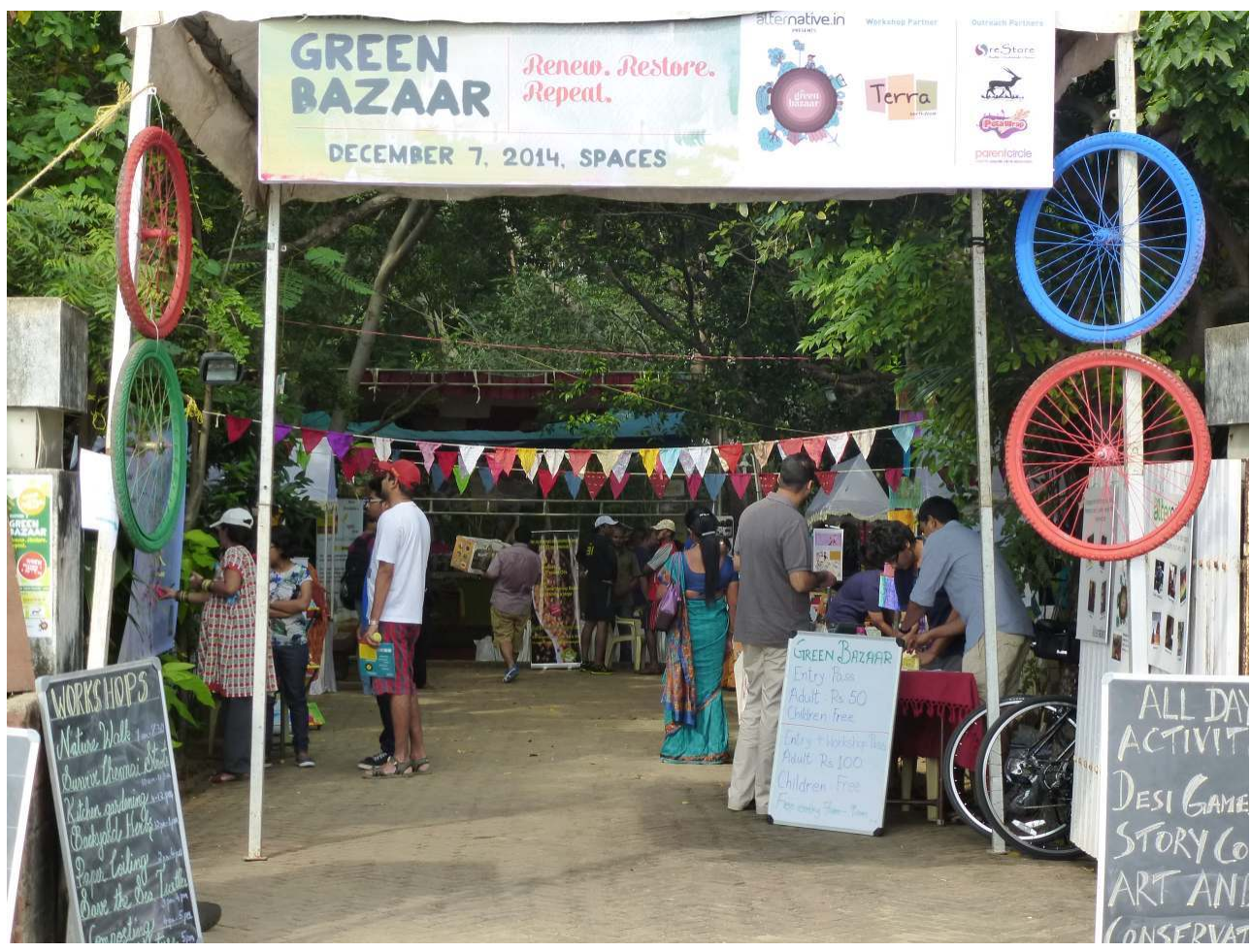

ChenNai's SECOND GREen BAZAAR, 2014

(PHOTOgRAPH BY: C. WOIWODE)

Actors aiming to induce societal change have spread through various niches of urban development. Many continue to work on a relatively small and circumscribed scale, and thus seek a transformative moment from below. Community learning via a quiet sensitisation is often at the heart of initiatives such as the kitchen garden (introduced above). The initiators consider it a teaching garden-e.g. a group of school children regularly participates in gardening and thus learns about food production or the value of organic waste. Beyond concrete skills, this involves a larger dimension of learning in the form of consciousness for urban sustainability by word of mouth in a "very slow and in a very unintentional way"-something the initiators observe among school children and within the initiators' families.

Third, our studies indicate a global or planetary meta-level at which discourses about the grand challenges are shaped by the Intergovernmental Panel for Climate Change, the Sustainable Development Goals and increasing debate about necessary socio-economic transitions towards sustainable societies (e.g. WBGU 2014). Such global interconnectivity is visible in two aspects: (i) many individuals we interviewed had returned from living abroad-e.g. Singapore, USA, Europe-where they were exposed to such ideas, witnessed and participated in similar projects; and (ii) access to and use of social media provides inspiration and examples of what is possible. We found global knowledge mobilities a crucial dimension in the emergence of local initiatives. Even though they are local, they are also embedded in transnational linkages or networks that connect them to globalscale citizens' movements promoting transitions to sustainability, fairness and justice. 


\section{Sustainable Chennai urbanism: Disruptions, contestations and confluences}

45 In urban India, local initiatives to change people's everyday life practices should be interpreted as "transformative moments" rather than scaled movements towards sustainable lifestyles and conscious consumption, for they are still niche activities of a minute urban minority. Nonetheless, they bear witness to the emergence of potentially powerful imaginaries of urban futures, a potential that may gain momentum. Specific, experimentally gained knowledge may reframe the relationships of citizens' groups with government. Two points of confluence of the discussed narratives demonstrate this potential shift in scale as well as the significance of the role of knowledge in the process. First, the state government invited a civic action group in Chennai that had been pioneering organic food production and distribution to contribute with their expertise to drafting an organic farming policy for Tamil Nadu several years ago. While the policy was eventually not adopted, it illustrates how such initiatives have relevant knowledge in specific areas, which may give them leverage to exert influence at the policy level. Second, the NMT Policy for Chennai emerged from up-scaled niche activities driven by citizens' groups that became an urban policy priority. The walkability movement to NMT Policy transition, however, is also an example of messier reality in sustainable Indian urbanism, i.e. a reality that is disrupted and contested yet may be productive, and where in the end only fractions of the original discourse endure. In the process of developing the policy, the range of actors involved in its formulation narrowed down to comprise those ready to forge coalitions and negotiate compromises with state actors.

Based on our findings, we would argue here for a different type of urban citizenship that to some extent defies the classification of urban middle-class activism, i.e. of a mostly self-referenced-like the RWAs-that is devoid of a larger concern for social and ecological issues (Kamath and Vijayabaskar 2009). In contrast, we observe a fledging new form of a "comprehensive global citizenship" at work with the "city as the locus of citizenship" (Desai and Sanyal 2012:8) that is acted out from the bottom up and intertwined with systemic change aspirations and with a conscious notion of transnational knowledge shared at the planetary scale. In addition, activities especially in the organic food sector also seek to reconnect the urban with the rural, and the (urban) consumer with the (rural) producer, thus attempting to create responsibilities and awareness of interdependence not only across space and territory but importantly across social strata, too. While there have been a number of environmental action groups in the city (see Harriss 2005), our argument considers citizens' initiatives which attempt to induce deeper change in people's thinking, values and worldviews based on recognition of global and local crises (beyond just the environment). This recognises the distinct role of ethics in the environmentally-conscious initiatives that go beyond their immediate neighbourhoods and materialise in "socio-ethical-ecological entrepreneurialism" rather than in paternalistic charity and philanthropy towards disadvantaged groups. This seems to be a more holistic response to the problems and challenges akin to movements like the Transition Town Initiatives (Hopkins 2008, www.transitionnetwork.org, Woiwode 2015). 


\section{Conclusion: Paths of sustainable Indian urbanism}

The empirical cases have underlined how diverse narratives of sustainable urbanism float in the city of Chennai. We discussed both current dynamics and coalitions for "grand visions" building on strategic planning, infrastructure and smart technologies for sustainability, and for green aspirations building on the self, societal learning and-in some cases-aspiring to become global transition movements. In conclusion, we link these to the Special Issue's theoretical debates concerning (1) urban citizenship and city making, (2) the role of knowledge in environmental politics, and (3) a situated urban political ecology.

First, in Chennai the two narratives and ongoing negotiations between them suggest different definitions, experiences and performances of citizenship. The "grand visions" for urban transformations promote an entrepreneurial understanding of citizenship, where citizens participating in growth-oriented development become the legitimisers of such visions. The proponents of "grand visions" illustrate a pathway to enable city administration and government to act, following mobile urbanisms from elsewhere, best practices of the "entrepreneurial" city. This is to be achieved in strategic partnerships that call for long-needed integration of sectoral planning and develop a large-scale, partly pre-emptive, approach to imagining the future city. Citizens here learn from experts, whereas experts take over the responsibility for city-making. What is not considered in this vision is the individual citizen's everyday life and how the emerging spatialities of "grand visions" potentially impact it. On the other hand, individual and collective action based on "green aspirations" understands citizens as (self-)learners, and thus the performance of citizenship as one of learning, responsibility and incremental change-making. Depending on the types of claims to urban spaces, such understandings of citizenship are supported, contested, tolerated or embraced by state institutions. Simultaneously, those claiming urban spaces continuously define their own relationship to state institutions, from cooperation to contestation. The initiatives we discussed are tolerated by state institutions, and progressive city authorities have started inviting them as important "others" in local debates.

Second, the emerging "green aspirations" in Chennai have underlined the need to recognise knowledge production emerging from urban lifestyle and consumption choices, and sketch a more holistic notion of sustainability. This is a fairly novel area of worlding practices, of being in urban India. However, it directly links the "consuming urban middle and upper classes" of India to the transnational level-global consumers in (post)industrialised countries face the same challenges. The pioneering niche initiatives are characterised by experimental learning-by-doing, the use of (global) social media, and by the knowledge mobilities initiated by NRIs returning to India. This learning process is often substantial, even more so when livelihoods are shifted from global knowledge industries to locally embedded activities such as organic food shops. Remarkably, both narratives of sustainable Indian urbanism, despite their often contrasting approaches to the urban, draw strongly on global knowledge mobilities-whether as policy transfers or individual lifestyle experiences.

Third, we observe the emergence of a "new era" of urban environmental politics in Chennai represented in some of its "flagship" policy interventions and project proposals, notably the NMT Policy, smart city development proposals and integrated public 
transport system. Simultaneously, as bottom-up movements, a number of activists as well as citizens' initiatives have sprung up across the city with niche social innovations towards sustainability, demonstrating a vivid "other" aiming for societal transition. Neither flagships nor niches, however, seem to account and act for the full stratum of urban diversity. While flagships as globally-acclaimed best practices may overlook emerging spatialities of social injustice, niche activities may similarly overlook another "other," being driven by the lifestyle and consumption choices of a still-elitist group of responsible citizens. Both, however, must be regarded as crucial for the emergence of a sustainable Indian urbanism, as it is the frictions, ruptures and confluences that make way for experiments towards larger sustainability transitions.

\section{BIBLIOGRAPHY}

Aam Janata. 2015. "Smart Cities or Cleverly-Disguised Corporate Colonies." Aam Janata (Intellectual Anarchy!), January 31. Retrieved March 23, 2015 (https://aamjanata.com/smart-cities-cleverlydisguised-corporate-colonies/).

Aggarwal, Rimjhim. 2013. "Strategic Bundling of Development Policies with Adaptation: An Examination of Delhi's Climate Change Action Plan." International Journal of Urban and Regional Research 37(6): 1902-15.

Appadurai, Arjun. 2001. "Deep Democracy: Urban Governmentality and the Horizon of Politics." Environment and Urbanization 13(2): 23-43.

Appadurai, Arjun. 2012. “Why Enumeration Counts.” Environment and Urbanization 24(2): 639-41.

Benjamin, Solomon. 2008. "Occupancy Urbanism: Radicalizing Politics and Economy beyond Policy and Programs." International Journal of Urban and Regional Research 32(3): 719-29.

Bulkeley, Harriet and Michele M. Betsill. 2013. "Revisiting the Urban Politics of Climate Change." Environmental Politics 22(1): 136-54.

Chatterjee, Partha. 2004. The Politics of the Governed: Reflections on Popular Politics in Most of the World . New York: Columbia University Press.

Datta, Ayona. 2015. “New Urban Utopias of Postcolonial India: 'Entrepreneurial Urbanization' in Dholera Smart City, Gujarat." Dialogues in Human Geography 5(1): 3-22.

Desai, Renu and Romola Sanyal. 2012. "Introduction." Pp. 1-30 in Urbanizing Citizenship: Contested Spaces in Indian Cities, edited by R. Sanyal and R. Desai. London: Sage.

Dixit, Rekha. 2015. “Dream de la Crème.” The Week, August 16, pp. 24-32.

Follmann, Alexander. 2015. “Urban Mega-Projects for a 'World-Class' Riverfront: The Interplay of Informality, Flexibility and Exceptionality along the Yamuna in Delhi, India.' Habitat International 45(3): 213-22.

Gandy, Matthew. 2008. "Landscapes of Disaster: Water, Modernity, and Urban Fragmentation in Mumbai." Environment and Planning A 40(1): 108-30. 
Ghertner, Asher. 2010. "The Nuisance of Slums: Environmental Law and the Production of Slum Illegality in India." Pp. 23-49 in Navigations: Politics, Space and the City in South Asia: Cities and the Urban Imperative, edited by J. S. Anjaria and C. McFarlane. New Delhi: Routledge India.

Goldman, Michael. 2011. "Speculative Urbanism and the Making of the Next World City." International Journal of Urban and Regional Research 35(3): 555-81.

Goldstein, James. 2006. “Sustainable Communities and the Great Transition.” GTI Paper Series No. 12. Boston: Tellus Institute.

Grin, John, Jan Rotmans and Johan Schot. 2010. Transitions to Sustainable Development: New Directions in the Study of Long Term Transformative Change. London: Routledge.

Gururani, Shubhra. 2013. “Flexible Planning: The Making of India's ‘Millennium City’ Gurgaon.” Pp. 119-142 in Ecologies of Urbanism in India: Metropolitan Civility and Sustainability, edited by K. Sivaramakrishnan and A. Rademacher, Hong Kong: Hong Kong University Press.

Harriss, John. 2005. "Middle Class Activism and Poor People's Politics: An Exploration of Civil Society in Chennai." Working Paper No. 05-72, Development Studies Institute (DESTIN), London School of Economics.

Hill, Chloe and Christoph Woiwode. 2016. "Peri-Urban Dynamics and Sustainability in Chennai: The Case of Sriperumbudur." Trialog (forthcoming).

Hirway, Indira and Piet Terhal. 2002. “The Contradictions of Growth.” Pp. 37-58 in Development and Deprivation in Gujarat, edited by G. Shah, M. Rutten and H. Streefkerk. New Delhi: Sage.

Homm, Sebastian. 2014. Global Players-Local Struggles: Spatial Dynamics of Industrialisation and Social Change in Peri-Urban Chennai, India. Stuttgart: Franz Steiner Verlag.

Hopkins, Rob. 2008. The Transition Handbook: From Oil Dependency to Local Resilience. Totnes, Devon: Green Books.

Jeelani, Mehboob. 2015. "Mayors Stumble on Smart City Mission.” The Hindu, Chennai, September 18.

Kaika, Maria and Eric Swyngedouw. 2014. "Urban Political Ecology: Great Promises, Deadlock... and New Beginnings?” Documents d'Anàlisi Geogràfica 60(3): 459-81.

Kamath, Lalitha and M. Vijayabaskar. 2009. "Limits and Possibilities of Middle-Class Associations as Urban Collective Actors." Economic and Political Weekly 44(26-27): 368-76.

Liedtke, Christa, Maria J. Welfens, Holger Rohn and Julia Nordmann. 2012. "Living Lab: UserDriven Innovation for Sustainability." International Journal of Sustainability in Higher Education 13 (2): $106-18$

Liedtke, Christa, Carolin Baedeker and Lisa Marie Borrelli. 2015. "Transformation towards a Sustainable Society: Key Intervention Area." Innovative Energy \& Research 4(117). doi:10.4172/ ier. 1000117

Lopez, Aloysius Xavier. 2015. "Response to Smart City Challenge a Let-Down." The Hindu, Chennai, October 13.

Mabin, Alan. 2014. "Grounding Southern City Theory in Time and Place." Pp. 21-36 in The Routledge Handbook on Cities of the Global South, edited by S. Parnell and S. Oldfield. Oxon: Routledge.

McCann, Eugene and Kevin Ward. 2011. Mobile Urbanism: Cities and Policymaking in the Global Age. Minneapolis: University of Minnesota Press. 
McFarlane, Colin. 2011. Learning the City: Knowledge and Translocal Assemblage. Malden, MA: WileyBlackwell.

MoUD (Ministry of Urban Development). 2015. Smart Cities: Mission Statement and Guidelines, Government of India, June.

Nair, Janaki. 2013. “Is There an 'Indian' Urbanism?” Pp. 43-70 in Ecologies of Urbanism in India: Metropolitan Civility and Sustainability, edited by K. Sivaramakrishnan and A. Rademacher. Hong Kong: Hong Kong University Press.

Nair, Janaki. 2014. "In Pursuit of Smartness.” The Hindu, Chennai, August 12.

Parnell, Susan and Jennifer Robinson. 2012. "(Re)theorizing Cities from the Global South: Looking Beyond Neoliberalism.” Urban Geography 33(4): 593-617.

Patel, Sheela, Carrie Baptist and Celine D'Cruz. 2012. "Knowledge is Power: Informal Communities Assert their Right to the City through SDI and Community-Led Enumerations." Environment and Urbanization 24(1): 13-26.

Raman, Nithya V. 2013. “The Messy Practice of Participation: Lessons from the City Development Plan (CDP) Review in Chennai." Pp. 276-97 in Participolis: Consent and Contention in Neoliberal Urban India, edited by K. Coelho, L. Kamath and M. Vijayabaskar. New Delhi: Routledge.

Robinson, Jennifer. 2006. Ordinary Cities: Between Modernity and Development. London: Routledge. Roy, Ananya. 2003. City Requiem, Calcutta: Gender and the Politics of Poverty. Minneapolis: University of Minnesota Press.

Roy, Ananya. 2009. “The 21st-Century Metropolis: New Geographies of Theory.” Regional Studies 43(6): 819-30.

Roy, Ananya. 2011. “Slumdog Cities: Rethinking Subaltern Urbanism." International Journal of Urban and Regional Research 35(2): 223-38.

Roy, Ananya. 2014. "Worlding the South: Toward a Post-Colonial Urban Theory." Pp. 9-20 in The Routledge Handbook on Cities of the Global South, edited by S. Parnell and S. Oldfield. Oxon: Routledge.

Roy, Ananya and Aiwha Ong. 2011. Worlding Cities: Asian Experiments and the Art of Being Global. Chichester, West Sussex, and Malden, MA: Wiley-Blackwell.

Schindler, Seth. 2014. “The Making of 'World-Class' Delhi: Relations between Street Hawkers and the New Middle Class." Antipode 46(2): 557-73.

Schneidewind, Uwe and Mandy Singer-Brodowski. 2013. Transformative Wissenschaft: Klimawandel im deutschen Wissenschafts- und Hochschulsystem [Transformative Science: Climate Change in the German Academic and Higher Education System] Marburg: Metropolis.

Shatkin, Gavin. 2014. "Contesting the Indian City: Global Visions and the Politics of the Local." International Journal of Urban and Regional Research 38(1): 1-13.

Shaw, Rajib and R.R. Krishnamurthy. 2010. "Chennai Zone Profile.” Climate and Disaster Resilience, Kyoto, Chennai. Retrieved November 18, 2013 (http://www.iedm.ges.kyotou.ac.jp/2011\%20update \%20files/new\%20reports/2010/CDRI\%20Chennai\%20small.pdf).

Sneha, Annavarapu. 2014. Consumption, Space and Identity: An Ethnographic Exploration of Isha Life, Chennai. Master's thesis, Department of Humanities and Social Sciences, Indian Institute of Technology, Madras.

Srivathsan, A. 2014. “A ‘Smart' Idea for Urban Ills?” The Hindu, Chennai, July 14. 
Tawa Lama-Rewal, Stéphanie and Marie-Hélène Zérah. 2011. “Introduction. Urban Democracy: A South Asian Perspective." SAMAJ: South Asia Multidisciplinary Academic Journal 5. Retrieved April 5, 2016 (http://samaj.revues.org/3188).

Temenos, Christina and Eugene McCann. 2012. "The Local Politics of Policy Mobility: The Education of Attention in Developing a Municipal Sustainability Fix." Environment and Planning 44: 1389-406.

The Economist. 2015. “The Gujarat Model.” The Economist, January 10.

Tolan, Casey. 2014. “Cities of the Future? Indian PM Pushes Plan for 100 'Smart Cities'.” CNN, July 18.

Tornaghi, Chiara. 2014. "Critical Geography of Urban Agriculture.” Progress in Human Geography 38 (4): 551-567.

UN-Habitat. 2009. Planning Sustainable Cities: Global Report on Human Settlements 2009. United Nations Human Settlements Programme. London and Sterling, VA: Earthscan.

UN-Habitat. 2012. State of the World's Cities 2012/2013: Prosperity of Cities, United Nations Human Settlements Programme. London and Sterling, VA: Earthscan.

Vassileva, Radina. 2015. “Green Mobility Aspirations: Civil Society's Role in the Development and Implementation of the Non-Motorized Transport Policy of Chennai." Master's thesis, Institute of Environmental Social Sciences and Geography, Freiburg University.

Vijay, Hema. 2014. "Sustainability is Smart." The Hindu, Chennai, August 23.

Watson, Vanessa. 2014. “African Urban Fantasies: Dreams or Nightmares?” Environment and Urbanization 26(1): 215-31.

WBGU (Wissenschaftlicher Beirat der Bundesregierung Globale Umweltveränderungen [German Advisory Council on Global Change]). 2011. World in Transition: A Social Contract for Sustainability. Flagship report.

WBGU (Wissenschaftlicher Beirat der Bundesregierung Globale Umweltveränderungen [German Advisory Council on Global Change]). 2014. Climate Protection as a Citizen Movement. Special Report. Weinstein, Liza. 2013. "Demolition and Dispossession: Toward an Understanding of State Violence in Millennial Mumbai." Studies in Comparative International Development 48(3): 285-307.

Weinstein, Liza. 2014a. “'One-Man Handled': Fragmented Power and Political Entrepreneurship in Globalizing Mumbai." International Journal of Urban and Regional Research 38(1): 14-35.

Weinstein, Liza. 2014b. The Durable Slum: Dharavi and the Right to Stay Put in Globalizing Mumbai. Delhi: Orient BlackSwan.

Wiig, Alan. 2015. “IBM’s Smart City as Techno-Utopian Policy Mobility.” City 19(2-3): 258-73.

Woiwode, Christoph. 2015. "Practical Spirituality and the Contemporary City: Awakening the Transformative Power for Sustainable Living." Gandhi Marg 36(4): 523-44.

World Bank. 2009. "Reshaping Economic Geography.” World Development Report 31, Washington, DC. 


\section{NOTES}

1. The state of Andhra Pradesh was divided in 2014, resulting in a coastal state with the same name and a new state: Telangana with Hyderabad as the capital.

2. Our use of the term urbanism refers to the processes that characterise the pathway of urban development in a certain period of time. These processes could emanate from statutory planning and its Leitbilder but may similarly be rooted in public discourses.

3. Our definition of mobilities here takes up McCann and Ward's (2011), who use the term "in the sense that people, frequently working in institutions, mobilize objects and ideas to serve particular interests and with particular material consequences" (McCann and Ward 2011:xxiv).

4. These Green Bazaars are organised by The Alternative.in, an organisation based in Bangalore promoting sustainable lifestyles. In 2014 and 2015, several such bazaars in Bangalore and Chennai showcased local activities of people and groups in organic farming, food, kitchen gardening, composting, recycling, etc.

5. A perspective on cities as ordinary-as opposed to previous hierarchical world-economy-based or developmentalist notions-“distributes the differences amongst cities as diversity rather than as hierarchical categories" (Robinson 2006:114) and thus opens up new categories for comparing diverse narratives of urbanism.

6. The Corporation of Chennai was renamed Greater Chennai Corporation in early 2016. For better readability we still use the old name.

7. The list of cities and their plans is available from the MoUD (http://smartcities.gov.in/ writereaddata/Ranking_of_Smart\%20Cities.pdf, retrieved March 9, 2016). In Tamil Nadu, Coimbatore and Chennai were selected.

8. It is instructive to read the comments posted on http://mygov.in/group-issue/chennai-globalsmart-city-making/.

9. Ponneri is not part of the Smart Cities Mission as it was conceptualised before its initiation.

10. Fieldnote by author, March 2015

11. Lobby group in urban development, interview by authors, Chennai, September 2014

12. Lobby group in urban development, interview by authors, Chennai, September 2014

13. Lobby group in urban development, interview by authors, Chennai, September 2014

14. Initiator of a kitchen garden, interview by authors, Chennai, September 2014

15. The first such initiative was started in the UK in 2007 to address future issues of climate change, peak oil, and the economic crisis. It soon became a movement with many such initiatives primarily across Europe and the US (Hopkins 2008).

16. Besides Chennai, we also conducted interviews in Bangalore, which we refer to at times to make a case.

17. "reStore" was founded in 2007 by a group of citizens who initiated one of the first organic food sales platforms from a garage in Chennai. They connected the producer directly with the customer without middlemen to ensure quality by purchasing the goods directly from organic farmers around the city. Due to its philosophy it quickly gained popularity, and now operates an Organic Farmers Market distributing to more than 15 independent shops across the city.

18. Member of reStore, interview by authors, Chennai, March 2015.

19. Member of a neighbourhood group on composting, interview by authors, Bangalore, March 2015.

20. Members of Nallakeerai, interview by authors, Chennai, March 2015. 
INDEX

Keywords: sustainable urban development, Indian urbanism, entrepreneurial city, urban practices, knowledge mobilities, Chennai

\section{AUTHORS}

\section{KIRSTEN HACKENBROCH}

Lecturer, Institute of Environmental Social Sciences and Geography, University of Freiburg

\section{CHRISTOPH WOIWODE}

Visiting Professor, Indo-German Centre for Sustainability, Indian Institute of Technology Madras, Chennai 